\title{
Phytotherapy: yesterday, today, and forever?
}

\author{
Ceci Mendes Carvalho Lopes ${ }^{1}$ \\ José Roberto Lazzarini² \\ (D) José Maria Soares Júnior ${ }^{3}$ \\ (iD) Edmund C. Baracat ${ }^{4}$
}

\begin{abstract}
1. Assistant Professor and Doctor of the Clínica Ginecológica of the Hospital das Clínicas da Faculdade de Medicina da Universidade de São Paulo, São Paulo/SP, Brasil. 2. Second treasurer of SOBRAFITO, São Paulo/SP, Brasil. 3. Associate Professor of Disciplina de Ginecologia do Departamento de Obstetrícia e Ginecologia, Hospital das Clínicas da Faculdade de Medicina da Universidade de São Paulo USP, São Paulo/SP, Brasil. 4. Full Professor of Disciplina de Ginecologia do Departamento de Obstetrícia e Ginecologia, Hospital das

Clínicas da Faculdade de Medicina da Universidade de São Paulof USP, São Paulo/SP, Brasil.
\end{abstract}

Since before we can remember, humans used natural resources at hand to fight whatever jeopardized their well-being. The earliest reference to this was found in China, in the writings of Emperor Cho Chin Ken, from around 3,000 B.C. There are references to approximately 1,700 medicinal plants in a papyrus from Egypt, and also data from peoples such as the Assyrians, Greeks, and others. ${ }^{1}$ Some places around the world, especially those with fewer economic resources, still adopt the same practices used back then. So much so, that the World Health Organization acknowledges phytotherapy as an important factor in primary health care. Much is achieved through traditional knowledge, which is usually passed from generation to generation. But the search to understand mechanisms of action, active principles, and scientific basis has been placed on the foreground.

The advance of chemistry and pharmacology, in the early 19th century, allowed for the first molecules to be isolated in a laboratory. Plants produce several substances that affect their metabolism, defense, adaptation to their environment, and even competition between species. These phytochemicals, which can act as agents to combat human diseases, started being identified and became increasingly known.
An important milestone in establishing phytotherapy as science was the creation, in 1976 Germany, of the Komission E, who sought to gather as much information as possible on plants that were considered medicinal, developing studies on each of them ${ }^{2}$. The importance of these studies is internationally recognized to this day. At the same time, the safeness and effectiveness of phytotherapics began to be demanded by the market. Furthermore, in order to normalize their offering, a means for standardizing the extracts was established.

To understand how that standardization works, it is necessary to know that the extract of any given plant is composed of several substances, some of which are biologically active, others that are secondary, all of which can have synergistic, or even antagonistic, actions. These components, in general, have a constant proportion. Thus, when a substance is identified, among all (ideally the active substance), its percentage in the extract will determine the others. And it is only possible to consider an extract similar to another when the amount of that marker is the same in both ${ }^{3}$.

As chemicals from plants were further studied, molecules were isolated - and also modified in lab- 
oratories -, and new highly effective compounded medications synthesized (although plant substances were often used as a base for the synthesis). For example, acetylsalicylic acid was synthesized from salicylic acid extracted from willows; it had fewer adverse effects and started to be widely used, with a patent and brand registration. These new compounds took over the market. Small pharmacies became the large industrial conglomerates we are familiar with today. Phytotherapy began to lose credibility, and its use decreased.

Evidence-Based Medicine started being developed, seeking to scientifically prove if certain products were safe, what were their effects, mechanisms of action, all of which gave more credibility to medications. Phytotherapics were often attacked as ineffective, and people saw them with doubt or suspicion. That motivated legislation in several countries. However, people continued to use phytotherapics. Research conducted in 2010 showed that around $70 \%$ of Germans used them, acknowledging, thus, its effectiveness but also demanding scientific confirmation ${ }^{4}$.

Currently, products derived from plants, overall, are not the primary option for emergencies. They can be complementarily used in cases of acute disease, are useful for several chronic diseases of mild to moderate intensity, and can be used in preventive care. However, they seem to be often used with no medical prescription and that are still many myths surrounding its use, such as "It can't hurt to try", "I don't need to tell my doctor that I used a phytotherapic because it is a natural product", and "It doesn't matter where the raw material comes from, it's all the same." Indeed, they usually do have fewer adverse effects and, in general, research shows that people who make use of phytotherapics are often those with greater concern for their health.

On the other hand, legislation on them varies from country to country. In the United States, for example, they are considered supplements and are not regulated by the FDA, despite their increasing use by the population. However, they face severe contamination and adulteration problems in the country, especially those of Chinese and Indian sources, which can cause adverse effects, serious ones included, and even death ${ }^{5}$. This has led three American non-governmental organizations - American Botanical Council-ABC, American Herbal Pharmacopea-AHP, and National Center for Natural Products Research - to start a wide-scale program to educate employees in the phytotherapics and supplements industries. The program intends to act as a self-regulating mechanism. Adulteration can happen accidentally, due to ineffective quality control , or intentionally aiming at financial gain.

Nowadays, a quality phytotherapic production process includes several stages. Cultivation must be controlled to ensure plants with constant quality levels. The raw material obtained at harvest must be pressed and dried for transport and storage, the storage location must be extremely clean and well-ventilated, and packages must be stored separately from other plants stored in the same facilities and away from the floor. The extracts obtained must be analyzed for their purity and dose of active principles.

The preparation of an extract also includes many careful stages. Firstly, the raw materials are turned into powder. Then, the powder is dissolved into an extracting solution (for each plant the most appropriate solvent is used: water, alcohol, ether, etc.). Next, the liquid is filtered, and an extract is obtained through the evaporation of the solvent and vacuum drying (the temperature is usually raised to $40^{\circ} \mathrm{C}$ or $50^{\circ} \mathrm{C}$ ). The extract is then used to produce the end product in the form of capsules, tablets, and others.

In emerging countries, it is estimated that $75 \%$ of the population uses natural products, while in developed countries that number is around $50 \%$ and mostly linked to lifestyle-related diseases. The traditional forms of use, such as in integrative medicine, Ayurveda, traditional Chinese medicine, homeopathy, acupuncture, and all other types of practice considered "alternative," have been increasingly adopted.

In Brazil, indigenous peoples already used plants to treat diseases, and the arrival of Africans and European Jesuits added to their knowledge ${ }^{1}$. There are historical, scientific sources on the use of medicinal plants, such as Flora Fluminensis, by Friar Mariano da Conceição Veloso (1742-1811); Systema Materia Medicae Vegetabilis Brasiliensis (1843), by Karl Friedrich Von Martius; Matéria Médica Brasileira (1862), by Manuel Freire Allemão Cysneros; and the Dicionário das Plantas Úteis do Brasil e das Plantas Exóticas Cultivadas, by Pio Correia, a collection of six volumes, published from 1926.

Brazilian legislation is stringent. However, despite this being an advantage, it makes it more difficult to launch new phytotherapics due to the severe requirements in quality and reference for clinical studies. Yet, most phytotherapics used in Brazil are produced using plants from other countries ${ }^{6}$. 
There are the traditional phytotherapics used as infusions or concoctions, tincture, syrups, or ointments, which include living pharmacies and the use of medicinal plants as a vegetable drug (the plant in natura). There are also the phytotherapics produced by the industry with different levels of technology and based on well-documented clinical evidence. That last category could use some innovation. Some phytotherapics are used in SUS (Brazilian Single Health System). Traditional products are exempt from prescription, unlike phytotherapic medications (also known as phytomedications), and the main difference between both categories is in the requirement for scientific proof.

For over a decade, there was a massive loss in the development and innovation of Brazilian phytotherapics due to the CGEN (Council for the Management of Genetic Heritage), which regulated research into Brazilian plants and set requirements that were often impossible to comply with, such as defining a legal representative in the community where a sample from a particular plant was collected. Several pieces of research were hampered due to legal uncertainty. In 2015, another law (Law 13.123/2015) was created to regulate the genetic access in the country, apparently improving the conditions for research and the equal distribution of the benefits derived from the economic exploitation of plant resources. The previous authorization by the CGEN is no longer necessary.

The first phytotherapic fully developed in the country and using exclusively Brazilian plants was an anti-inflammatory based on Cordia verbenacea, a bush from the Amazon Forest traditionally used for reducing inflammation. It was launched in 2005 and soon became a leader in medical prescriptions.

State policies are now favorable. The industry seems to be aligning themselves, and the academia has been developing studies that still lack cohesion. There still the need to perfect the several elements involved. There is a demand, not only from the industry but from the government (SUS) and the academia (scientific production). It is necessary to implement a food network of producers for the extracts, including family farming and sustainability. We need to develop studies of basic research, pharmaceutical analytics, and techniques, followed by clinical trials so that finally the medication can be included in the Anvisa records and registered to be marketed. It is a long road, and everything depends on its harmonic balance.
In 2007, the PNPMF (National Program of Medicinal Plants and Phytotherapics) was implemented with the purpose of ensuring the Brazilian population access to the secure and rational use of medicinal plants and phytotherapics, promoting the sustainable use of biodiversity, developing the production chain and national industry. The PNPIC (National Program of Integration and Complementary Practices) was instituted and included several so-called "alternative" approaches, including the phytotherapy. As part of the program, medications based on 12 plants were approved and distributed by the Ministry of Health to the municipalities, who then forward them to the Basic Health Units. Unfortunately, the program is still unknown by many, so it is underused. There is also a list of 71 plants in which the government is interested in studying so that they can, in the future, be included in the Rename (National List of Medications).

Although phytotherapy is not a subject included in the curriculum of most medical schools in the country, it has been widely studied in pharmacy faculties. In post-graduate programs, however, thousands of dissertations have been developed and presented throughout Brazil on the subject of medicinal plants ${ }^{8-11}$. Unfortunately, once they are defended, they are published but not put into practice, with few exceptions.

Brazil has incredible biodiversity (15-20\% of the world's biodiversity), with about 60,000 varieties of plants. Nonetheless, only approximately 1,500 of those are documented. In the words of the American biologist Thomas Lovejoy: "It is counterintuitive that this potential is completely understudied and underused in programs for the discovery of natural substances for the most diverse applications."

Many health professionals are interested in phytotherapics, especially pharmacists and nutritionists. But dentists, veterinarians, and physical therapists also find uses for its application. Doctors, however, often still have restrictions regarding them. In research conducted with doctors in Brazil, 95\% declared that they would prescribe them more often if there were studies to prove their security and effectiveness. They would also like more information (since there is no subject on phytotherapy in medical school) and claim to prescribe them when there are restrictions for treatment with synthetics. Only 5\% declared having no intention of prescribing phytotherapics. 
On the other hand, there is an increase in interest by the population in this type of medication ${ }^{12}$, which is linked to an increasing interest in improving lifestyle conditions. All of that leads us to believe that

\section{REFERENCES}

1. História e origem da fitoterapia. [cited 2018 Aug 12]. Available from: http://www.dicasdemassagem.com/historia-e-origem-da-fitoterapia

2. Commission E. [cited 2018 Aug 12]. Available from: https://en.wikipedia. org/wiki/Commission_E

3. Schulz V, Hänsel R, Tyler VE. Fitoterapia racional: um guia de fitoterapia para as Ciências da Saúde. 4a ed. São Paulo: Manole; 2002.

4. El Dib RP. Como praticar a Medicina baseada em evidências. J Vasc Bras. 2007;6(1):1-4.

5. Posadzki P, Watson L, Ernst E. Contamination and adulteration of herbal medicinal products (HMPs): an overview of systematic reviews. Eur | Clin Pharmacol. 2013;69(3):295-307.

6. Costa V. Participação dos fitoterápicos no mercado brasileiro é ainda muito aquém do seu potencial e liderado por produtos estrangeiros, alerta especialista. [cited 2018 Aug 12]. Available from: http://prosperdistribuidora. com.br/participacao-dos-fitoterapicos-no-mercado-brasileiro-e-ainda-muito-aquem-do-seu-potencial-e-liderado-por-produtos-estrangeiros-alerta-especialista/

7. Brasil. Ministério da Saúde. Plantas medicinais e fitoterápicos no SUS [cited 2018 Aug 12]. Available from: http://portalms.saude.gov.br/acoes- the adoption of measures is of the essence, not only to educate the population and the professionals, but also to increase quality in raw materials, research, and innovation. e-programas/programa-nacional-de-plantas-medicinais-e-fitoterapicos-ppnpmf/plantas-medicinais-e-fitoterapicos-no-sus

8. Carbonel AAF, Lima PDA, Lim IJ, Fuchs LFP, Paiotti APR, Sasso GRDS, et al. The effects of soybean isoflavones and $17 \beta$-estradiol in uterus and mammary glands of diabetic rat models. Gynecol Endocrinol. 2018;34(4):314-9.

9. del Giorno C, Fonseca AM, Bagnoli VR, Assis JS, Soares JM Jr, Baracat EC. Effects of Trifolium pratense on the climacteric and sexual symptoms in postmenopause women. Rev Assoc Med Bras. 2010;56(5):558-62.

10. Carbonel AA, Baracat MC, Simões RS, Simões MI, Baracat EC, Soares IM Ir. The soybean concentrated extract proliferates the vagina of adult rats. Menopause. 2011;18(1):93-101.

11. Kaari C, Haidar MA, Soares Júnior JM, Nunes MG, Quadros LG, Kemp C, et al. Randomized clinical trial comparing conjugated equine estrogens and isoflavones in postmenopausal women: a pilot study. Maturitas. 2006;53(1):49-58

12. Brasil. Ministério da Saúde. Uso de plantas medicinais e fitoterápicos sobe 161\%. [cited 2018 Aug 12]. Available from: http://www.brasil.gov.br/editoria/saude/2016/06/uso-de-plantas-medicinais-e-fitoterapicos-sobe-16 